\title{
Analisis Yuridis Perilaku Lesbian dari Seorang Isteri sebagai Alasan Perceraian
}

\section{Yuridical Analysis of Lesbian Behavior from a Wife as a Divorce Reasons}

\author{
Lita Mardani Siregar* \\ Program Studi Magister Hukum, Fakultas Hukum, \\ Universitas Islam Sumatera Utara, Indonesia
}

Diterima: November 2019; Disetujui: Desember 2019; Dipublish: Desember 2019

*Coresponding Email: litamardani@gmail.com Abstrak

Salah satu prinsip dalam hukum perkawinan nasional yang sejalan dengan ajaran agama adalah mempersulit terjadinya perceraian (cerai hidup), karena perceraian berarti gagalnya tujuan perkawinan untuk membentuk keluarga yang bahagia dan kekal sejahtera akibat perbuatan manusia. Permasalahan dalam penelitian ini adalah bagaimana pengaturan pelaksanaan perceraian di Pengadilan Agama, bagaimanakah akibat hukum perceraian dengan alasan perilaku lesbian dari seorang isteri, bagaimanakah pertimbangan hakim dalam putusan Pengadilan Agama Ambon Nomor 110/Pdt.G/2016/PA Ab. Akibat hukum terhadap harta perkawinan yaitu harta bersama dibagi menurut ketentuan hukum, undang-undang, agama dan hukum adat masing-masing yang berlaku, sedangkan harta bawaan tetap dikuasai masing-masing pihak isteri maupun suami yang bercerai. Terhadap hutang piutang yang diakibatkan putusnya perkawinan akibat perceraian dipikul oleh kedua belah pihak dengan persyaratan yang harus dipenuhi dimana hak dan kewajiban suami dan isteri adalah seimbang dalam kewenangannya untuk melakukan perbuatan hukum. Pertimbangan hakim dalam putusan Pengadilan Agama Ambon Nomor 110/Pdt.G/2016/PA Ab dalam kasus kelainan seksual (lesbian) langsung menimbang bahwa hal tersebut sesuai dengan ketentuan dalam Pasal 39 ayat 2 Undang-Undang Nomor 1 Tahun 1974 beserta penjelasannya pada huruf e dan huruf f juncto Pasal 19 huruf f Peraturan Pemerintah Nomor 9 Tahun 1975, Pasal 116 huruf e dan huruf f Inpres No. 1 Tahun 1991 tentang Kompilasi Hukum Islam (KHI).

Kata Kunci: Lesbian, Isteri, Perceraian

Abstract

One of the principles in national marriage law that is in line with religious teachings is to make divorce difficult (divorce), because divorce means the failure of the purpose of marriage to form a happy and eternal family due to human actions. The problem in this reshearch is how is the regulation of the implementation of divorce in the Religious Court, what is the effect of the divorce law on the grounds of lesbian behavior of a wife, how is the consideration of the judge in the Ambon Religious Court decisionNumber 110 / Pdt.G / 2016 / PA Ab. As a result of divorce law on the grounds that the lesbian behavior of a wife is related to child custody. The legal effect on marital property is that joint property is divided according to the provisions of the respective laws, laws, religion and customary law, while the inheritance remains controlled by each of the wives and divorced husbands. With regard to debt due to termination of marriage due to divorce borne by both parties with conditions that must be met where the rights and obligations of husband and wife are balanced in their authority to carry out legal actions. Judge's consideration in the decision of the Ambon Religious Court Number 110 / Pdt.G / 2016 / PA Ab in the case of sexual disorders (lesbians) immediately considers that this is in accordance with the provisions in Article 39 paragraph 2 of Law Number 1 of 1974 along with the explanation in letter e and letter f juncto Article 19 letter f Government Regulation Number 9 of 1975, Article 116 letter e and letter finpres No. 1 of 1991 concerning the Compilation of Islamic Law (KHI).

Keywords: Lesbians, Wife, Divorce

How to Cite: Siregar, L.M. (2019). Analisis Yuridis Perilaku Lesbian Dari Seorang Isteri Sebagai Alasan Perceraian (Studi Kasus Putusan Pengadilan Agama Ambon Nomor 110/Pdt.G/2016/PA Ab). Journal of Education, Humaniora and Social Sciences (JEHSS). 2 (2): 383-398. 


\section{PENDAHULUAN}

Perkawinan merupakan suatu cara untuk menyalurkan kebutuhan biologis antara laki-laki dan wanita dan menghubungkannya sebagai suami isteri. Hal tersebut merupakan suatu ikatan yang paling kuat dalam hubungan pergaulan manusia (Mukhtar, 2013.). Sebagaimana yang disebutkan dalam Pasal 1 Undang-Undang Nomor 1 Tahun 1974 Tentang Perkawinan (selanjutnya disebut UU Perkawinan) bahwa yang dimaksud dengan perkawinan ialah ikatan lahir dan batin antara seorang pria dan wanita sebagai suami isteri dengan tujuan untuk membentuk keluarga (rumah tangga) yang bahagia dan kekal berdasarkan ketuhanan Yang Maha Esa“.

Munculnya fenomena lesbian, gay, biseksual, dan transgender (selanjutnya disebut LGBT) di tengah masyarakat yang pada hakikatnya adalah kelainan dan penyimpangan seksual. Aktivitas LGBT bertentangan dengam Pancasila sila 1 dan sila 2, Undang-Undang Dasar Tahun 1945 khususnya Pasal 29 ayat (1) dan Pasal 28 dan UU Perkawinan.

Aktifitas LGBT bertentangan dengan fatwa MUI Nomor 57 Tahun 2014 yaitu tentang Lesbian, Gay, Sodomi, dan Pencabulan. Fatwa ini dinyatakan bahwa homoseksual, baik lesbian maupun gay dan sodomi hukumnya adalah haram. LGBT merupakan bentuk kejahatan (jarimah) oleh karena itu kapada pelakunya dapat dikenakan hukuman hadd atau ta'zir oleh pihak berwenang.

Imam Malik, Asy-Syafi'i, Ahmad bin Hanbal, Syi'ah Imamiyah, dan Syi'ah Zaidiyah berpendapat bahwa persetubuhan yang diharamkan, baik dalam kubul maupun dubur, pada laki-laki maupun perempuan, hukumnya sama. Pendapat ini juga disepakati oleh Muhammad dan Abu Yusuf, murid Imam Abu Hanifah. Alasan menyamakan persetubuhan dubur dan zina dalam satu makna sehingga mewajibkan hukuman hudud adalah dengan adanya persetubuhan yang diharamkan. Ini termasuk zina, terutama $\mathrm{Al}$ Qur'an telah menyamakan keduanya (Audah, 2007).

Qs. Asy-Syua'ra': 165-166 berfirman yang artinya: Mengapa kamu mendatangi jenis lelaki di antara manusia, dan kamu tinggalkan isteri-isteri yang dijadikan oleh Tuhanmu untukmu, bahkan kamu adalah orang-orang yang melampaui batas". Hadis diriwayatkan oleh Baihaqi, artinya: Apabila laki-laki hubungan intim dengan laki-laki (homoseksual) maka keduanya adalah pezina, dan apabila perempuan melakukan hubungan intim dengan perempuan (lesbian)maka keduanya juga adalah pezina (Djubaedah, 2010). 
Keutuhan dan kerukunan rumah tangga yang bahagia, aman, tenteram dan damai merupakan dambaan setiap orang dalam rumah tangga. Negara Republik Indnesia adalah negara yang berdasarkan Ketuhanan Yang Maha Esa dijamin oleh Pasal 29 Undang-Undang Dasar 1945. Dengan demikian, setiap orang dalam lingkup rumah tangga dalam melaksanakan hak dan kewajibannya harus didasari oleh agama. hal ini perlu terus ditumbuh kembangkan dalam rangka membangun keutuhan rumah tangga. Mewujudkan keutuhan dan kerukunan tersebut sangat tergantung pada setiap orang dalam lingkup rumah tangga, terutama kadar kualitas perilaku dan pengendalian diri setiap orang dalam lingkup rumah tangga tersebut.

Sudah menjadi kodrat alam, bahwa dua orang manusia dengan jenis kelamin yang berlainan seorang wanita dan seorang laki-laki, ada rasa saling tertarik antara satu sama lain untuk hidup bersama. Hidup bersama ini sangat penting di dalam kehidupan bermasyarakat, bahwa dengan hidup bersama antara dua orang manusia itu, mereka tidak dapat memisahkan diri dari anggota-anggota lain dari masyarakat. Namun keputusan untuk hidup bersama ini harus berdasarkan hukum yang berlaku di Indonesia. Indonesia mengatur tentang hidup bersama yang disebut dengan lembaga perkawinan (Sastroatmojo, 2008).

Perkawinan dalam Islam tidaklah semata-semata sebagai hubungan atau kontrak keperdataan biasa, akan tetapi ia mempunyai nilai ibadah. Maka amatlah tepat jika Kompilasi Hukum Islam menegaskannya sebagai akad yang sangat kuat (mitsaqon gholiidan) dan untuk mentaati perintah Allah dan melaksanakannya merupakan ibadah (Pasal 2 Kompilasi Hukum Islam) (Ichsan, 2006).

Perkawinan merupakan salah satu perintah agama kepada yang mampu untuk segera melaksanakannya, karena dengan perkawinan dapat mengurangi maksiat penglihatan, memelihara diri dari perbuatan zina. Oleh karena itu, bagi mereka yang berkeinginan untuk menikah, sementara perbekalan untuk memasuki perkawinan belum siap, dianjurkan berpuasa. Dengan berpuasa, diharapkan dapat membentengi diri dari perbuatan tercela yang sangat keji yaitu perzinahan.

Dinyatakan dalam hadis riwayat dari Bukhari dan Muslim, Rasulullah SAW, bersabda yang artinya : "Hai pemuda, barangsiapa di antara kamu berkeinginan hendak nikah (kawin) hendaklah ia kawin (nikah), karena sesungguhnya perkawinan itu akan 
menjauhkan mata terhadap orang yang tidak halal dilihatnya dan akan memeliharanya dari godaan syahwat" (Ramulyo, 2006).

Perkawinan merupakan wadah penyaluran kebutuhan biologis manusia yang wajar, dan dalam ajaran Nabi, perkawinan ditradisikan menjadi sunnah beliau. Hadits riwayat Anas ibnu Malik, bahwa sayalah yang paling bertaqwa kepada Tuhan, namun saya ini shalat, tidur, puasa, berbuka, dan aku menikah, itulah sunnahku barangsiapa yang tidak mengikuti sunnahku bukanlah umatku" (Ramulyo, 2006).

Berdasarkan hal di atas tampak bahwa perkawinan merupakan hal yang memang disunnahkan oleh Rasul dan disenangi Allah. Namun dari ikatan perkawinan tidak menjamin bahwa sebuah keluarga akan mendapatkan kebahagiaan, adakalanya perkawinan memicu pertengkaran antara suami isteri dan karena berbagai sebab.

Semua manusia mengharapkan kehidupan perkawinannya dapat berlangsung terus hingga akhir hayatnya. Hal ini diperkuat sebagaimana dalam UU Perkawinan yang menegaskan bahwa prinsip perkawinan adalah suatu akad yang suci yang dibangun oleh suami-istri dengan tujuan membentuk rumah tangga yang kekal dan bahagia. Namun tak dapat dipungkiri kehidupan rumah tangga tak luput dari permasalahan-permasalahan yang timbul baik disengaja ataupun tidak sehingga dapat menimbulkan perselisihan rumah tangga. Perselisihan-perselisihan yang terjadi harus dapat diselesaikan secara proporsional. Artinya bahwa apabila penyebab dari perselisihan tersebut adalah suatu kesalahan kecil yang tidak disengaja oleh salah satu pihak, harus diselesaikan secara damai, tidak perlu diselesaikan dalam jalur hukum.

Perkawinan harus dipertahankan semaksimal mungkin oleh suami-istri. Pada prinsipnya Undang-Undang Perkawinan di Indonesia menganut ketentuan mempersukar atau mempersulit terjadinya perceraian. Kalaupun terjadi perceraian, hal tersebut merupakan jalan akhir yang akan ditempuh apabila memang perkawinan tersebut tidak dapat dipertahankan lagi. Perkawinan dapat diputus apabila terjadi karena alasan-alasan yang prinsipil, yang apabila rumah tangganya dipertahankan akan terjadi kemadharatan dan dampak buruk yang lebih besar daripada dampak positifnya atau dengan kata lain, bercerai akan lebih besar manfaatnya daripada tetap menjalin kehidupan rumah tangga.

Prinsipnya tujuan perkawinan membentuk keluarga yang bahagia dan kekal. Hal ini ditegaskan dalam UU Perkawinan yaitu ucapan lahir batin antara seorang pria dengan seorang wanita sebagai suami istri dengan tujuan membentuk keluarga (rumah tangga) 
yang berbahagia dan kekal berdasarkan ketuhanan Yang Maha Esa. Namun, terkadang fenomena berbicara lain, perkawinan yang diharapkan sakinah, mawadah, warohmah ternyata karena satu dan lain hal harus kandas di tengah jalan. Kondisi rumah tangga mengalami perselisihan, pertengkaran serta suami istri sudah tidak dapat lagi di damaikan maka Islam memberi solusi dengan perceraian atau talaq. Perceraian atau talaq merupakan obat terakhir untuk mengakhiri pertentangan dan pergolakan antara suami istri serta menjadi jalan keluar yang layak untuk keduanya.

Salah satu prinsip dalam hukum perkawinan nasional yang sejalan dengan ajaran agama adalah mempersulit terjadinya perceraian (cerai hidup), karena perceraian berarti gagalnya tujuan perkawinan untuk membentuk keluarga yang bahagia dan kekal sejahtera akibat perbuatan manusia. Lain halnya jika terjadinya putus perkawinan karena kematian yang merupakan takdir dari Tuhan Yang Maha Esa yang tidak dapat dihindarkan oleh manusia. Keutuhan dan kerukunan rumah tangga dapat terganggu jika kualitas dan pengendalian diri tidak dapat dikontrol yang pada akhirnya dapat terjadi kekerasan dalam rumah tangga sehingga timbul ketidak adilan terhadap orang yang berada dalam lingkup rumah tangga tersebut.

Perceraian merupakan bagian dari perkawinan, sebab tidak ada perceraian tanpa adanya perkawinan lebih dahulu. Perkawinan merupakan awal dari hidup bersama antara seorang pria dengan seorang wanita yang diatur dalam peraturan perundangundangan dalam suatu negara, sedangkan perceraian merupakan akhir dari kehidupan bersama suami isteri tersebut.

Menurut A. Fuad Said sebagaimana dikutip oleh Abdul Manan menyebutkan bahwa perceraian adalah "putusnya perkawinan antara suami isteri karena tidak terdapat kerukunan dalam rumah tangga atau sebab lain seperti mandulnya isteri atau suami" (Manan, 2003).

Timbulnya permasalahan dalam rumah tangga yang mengakibatkan terjadinya perceraian adalah isteri tidak mau memberikan nafkah batin kepada suaminya dengan alasan adanya faktor kelainan seks pada isteri. Kelainan seks tersebut salah satunya yaitu isteri lebih menyukai sesama jenis (lesbian) dari pada lawan jenisnya, atau yang dikenal dengan istilah lesbi. Lesbi adalah hubungan badan antara sesame jenis, antara wanita dengan wanita lainnya. 
Adanya kelainan seks tersebut, isteri tidak mau memberi nafkah bathin kepada suaminya yang disebabkan isterinya lebih menyukai orang lain sesama jenis, tidak tertarik dengan suaminya sehingga akibatnya suami akan menjadi korban karena isterinya tidak bisa atau tidak mampu menjalankan tugasnya sebagai seorang isteri, kemudian suami hidup tanpa ketenangan dan kasih saying. Apabila dihubungkan dengan Undang-Undang Perkawinan dan Kompilasi Hukum Islam, maka jelas bahwa perceraian (putusnya perkawinan) diperbolehkan jika salah satu pihak mendapat cacat badan atau penyakit dengan akibat tidak dapat menjalankan kewajiban sebagai suami/isteri.

Contoh kasus suami istri yang bercerai karena ternyata sang istri lesbian seperti terungkap dalam putusan Pengadilan Agama Ambon Nomor 110/Pdt.G/2016/PA.Ab. Suami mengajukan permohonan cerai atas istrinya karena suami tidak mendapat layanan batin dari sang istri yang mengakibatkan mulai terjadinya percekcokan.

Sejak bulan Juni 2010 kehidupan rumah tangga Pemohon dan termohon mulai tidak harmonis ditandai dengan adanya perselisihan dan pertengkaran disebabkan antara lain: 1) Termohon tidak mau mendengar kata-kata suami; 2) Termohon tidak mau memberikan nafkah bathin kepada Pemohon; 3) Termohon mengaku sebagai LGBT.

Puncak keretakan hubungan rumah tangga antara Pemohon dengan Termohon tersebut terjadi pada bulan September 2010. Saat itu Termohon tidak mau melayani Pemohon sebagaimana layaknya suami istri. Sejak saat itu Pemohon dan Termohon telah pindah rumah, masing-masing pihak tidak lagi menjalankan kewajibannya sebagai suami istri.

\section{METODE PENELITIAN}

Metode penelitian adalah upaya untuk menemukan, mengembangkan dan menguji kebenaran suatu pengetahuan dimana usaha tersebut dilakukan dengan menggunakan metode ilmiah (Hadi, 2009). Metode penelitian berisikan uraian tentang metode atau cara yang peneliti gunakan untuk memperoleh data atau informasi. Metode penelitian berfungsi sebagai pedoman dan landasan tata cara dalam melakukan oprasional penelitian untuk menulis suatu karya ilmiah yang peneliti lakukan (Ali, 2009).

Penelitian ini bersifat deskriptif analitis. Bersifat deskriptif maksudnya penelitian ini diharapkan diperoleh gambaran secara rinci dan sistematis tentang permasalahan yang diteliti. Analitis dimaksudkan berdasarkan gambaran fakta yang diperoleh akan dilakukan secara cermat bagaimana menjawab permasalahan. Jadi deskriptif analitis 
maksudnya adalah untuk menggambarkan, menjelaskan, dan menganalisis permasalahan dari setiap temuan data baik primer maupun sekunder, langsung diolah dan dianalisis untuk memperjelas data secara kategoris, penyusunan data secara sistematis, dan dikaji secara logis (Abdurrahman, 2009).

Sesuai dengan permasalahan dan tujuan penelitian, maka jenis penelitian yang digunakan adalah jenis penelitian yuridis normatif (Soemitro, 1998). Jenis penelitian yang digunakan dalam penelitian ini adalah penelitian hukum normatif dengan cara meneliti bahan kepustakaan atau bahan data sekunder yang meliputi buku-buku serta normanorma hukum yang terdapat dalam peraturan perundang-undangan, asas-asas hukum, kaedah hukum dan sistematika hukum serta mengkaji ketentuan perundang-undangan, putusan pengadilan dan bahan hukum lainnya yang relevan dengan perumusan penelitian (Johni, 2005).

Jenis penelitian yang dilakukan dalam penyusunan tesis ini menggunakan metode penelitian hukum normatif (yuridis normatif). Penelitian yuridis normatif adalah penelitian hukum yang mengacu pada norma-norma hukum yang terdapat pada peraturan perundang-undangan (Johni, 2005). Meniliti bahan kepustakaan atau data sekunder yang mencakup asas-asas hukum sistematika hukum, taraf sinkronisasi vertikal dan horizontal, perbandingan hukum dan sejarah hukum (Soekanto, 1998).

Penelitian menggunakan pendekatan perundang-undangan (statute aproach) dalam dengan menganalisis tentang perlindungan hukum terhadap anak dibawah umur akibat tindak pidana sodom dalam putusan Pengadilan Agama Ambon Nomor 110/Pdt.G/2016/PA Ab dan pendekatan kasus (The Case Approach). Pendekatan kasus adalah pendekatan yang dilakukan dengan cara melakukan telaah terhadap kasus-kasus yang berkaitan dengan isu yang dihadapi yang telah menjadi putusan pengadilan yang telah mempunyai kekuatan hukum yang tetap.

Data dalam penelitian ini diperoleh melalui data sekunder yaitu data yang dikumpulkan melalui studi terhadap bahan kepustakaan. Data sekunder yaitu data yang diperoleh dari dokumen-dokumen resmi, buku-buku yang berhubungan dengan objek penelitian, dan peraturan perundang-undangan. Data sekunder dalam penelitian ini mencakup: a) Bahan hukum primer terdiri dari : 1) Norma atau kaidah dasar yaitu UUD NRI Tahun 1945; 2) Kompilasi Hukum Islam; 3) Undang-Undang Nomor 1 Tahun 1974 Tentang Perkawinan; 4) Peraturan Pemerintah Nomor 9 Tahun 1975 Tentang 
Pelaksanaan Undang-Undang Nomor 1 Tahun 1974 Tentang Perkawinan; 4) Putusan Pengadilan Agama Ambon Nomor 110/Pdt.G/2016/PA Ab.

Bahan hukum sekunder, yakni bahan yang memberikan penjelasan mengenai bahan hukum primer, seperti hasil-hasil seminar, atau pertemuan ilmiah lainnya, internet bahkan dokumen pribadi atau pendapat dari kalangan pakar hukum sepanjang relevan dengan objek penelitian ini; Bahan hukum tersier adalah bahan hukum penunjang yang memberi petunjuk dan penjelasan terhadap bahan hukum primer dan bahan hukum sekunder, seperti kamus hukum, kamus hukum, majalah dan jurnal ilmiah, serta internet yang menjadi tambahan bagi penulisan tesis ini sepanjang memuat informasi relevan dengan penelitian yang dilakukan

Teknik pengumpulan data yang digunakan dalam penelitian ini adalah studi pustaka (library research) dengan alat pengumpulan data berupa studi dokumen. Menurut Soerjono Soekanto bahwa yang dimaksud dengan penelitian kepustakaan yaitu penelitian terhadap data sekunder.

Analisis data didalam penelitian ini, dilakukan dengan pendekatan kualitatif karena penelitian ini akan berupaya untuk memaparkan sekaligus melakukan analisis terhadap permasalahan yang ada dengan kalimat yang sistematis untuk memperoleh kesimpulan jawaban yang jelas dan benar (Soekanto,). Sebelum analisis dilakukan, terlebih dahulu diadakan pemeriksaan dan evaluasi terhadap semua data yang telah dikumpulkan untuk diketahui validitasnya (Sunggono, 2008).

Penelitian ini menggunakan metode kualitatif dengan penarikan kesimpulan berupa penarikan kesimpulan deduktif. Penalaran deduktif atau deduksi adalah merupakan suatu proses berpikir (penalaran) yang bertolak dari sesuatu proposisi yang sudah ada, menuju kepada suatu proposisi baru yang berbentuk suatu kesimpulan.

\section{HASIL DAN PEMBAHASAN}

\section{Akibat Hukum Perceraian Dengan Alasan Perilaku Lesbian Dari Seorang Isteri}

Menurut Bahasa Lesbian berarti memiliki kelainan seksual yang sama. Sedangkan menurut istilah lesbi berarti ketertarikan seseorang untuk mengadakan hubungan seks dengan orang lain yang berjenis kelamin sama, dalam hal ini terkhusus perempuan dengan perempuan (Musa, 2006). Dalam Ensiklopedi Indonesia, lesbian adalah istilah bagi perempuan yang mengarahkan orientasi seksualnya kepada perempuan atau disebut juga perempuan yang mencintai perempuan lain baik secara fisik, seksual, 
emosional, atau secara sepiritual. Pada saat ini lesbian digunakan untuk menunjuk kaum gay wanita (Sadhily, 2015).

Menurut Marzuki Umar Sa'abah menuturkan bahwa lesbi adalah rasa tertarik dan mencintai sesama jenis.U ntuk kaum pria dikenal sebagai kaum gay, sedangkan untuk kaum perempuan dikenal sebagai kaum lesbi (Sadhily, 2015). Dengan demikian mereka yang mempunyai kelainan seperti itu secara tidak sadar identitas diri mereka telah bertentangan dengan identitas sosial di suatu komunitas masyarakat.

Semua ulama Muslim sepakat bahwa hubungan kelamin sesama jenis merupakan suatu pelanggaran seks, dan merupakan perbuatan yang keji. Menurut Sayyid Qutub, sebuah keanehan yang terdapat dalam pernyataan kaum Luth, yang pertama adalah suatu perbuatan keji yang mereka lakukan, padahal mereka menyaksikan sendiri kehidupan dalam segala macam dan jenisnya yang berjalan diatas fitrah, dan mereka sendirilah yang menimbulkan sebuah penyimpangan dan perbuatan aneh. Kemudian pernyataan kedua, dia membuka sejelas-jelasnya perbuatan keji yang mereka lakukan. Dengan menyikapi seperti itu saja, sudah cukup menunjukan bahwa perbuatan tersebut sangat aneh dalam kesadaran manusia dan kesadaran fitrah semua mahluk (Sadhily, 2015).

Lesbi, tidak terdapat Undang-undang perdata yang secara jelas mengatur tentang hal ini, namun hal tersebut bisa dimasukan pada peraturan yang mengatur tentang perceraian sebab penyakit yang berakibat salah satu pasangan tidak mampu menjalankan kewajibannya sebagai suami atau isteri yang terdapat dalam Inpres No.1 tahun 1991 tentang Kompilasi Hukum Islam pasal 116 point e.

Undang-undang Nomor 1 Tahun 1974 Tentang Perkawinan dan Peraturan Pemerintah Nomor 9 tahun 1975 Tentang Pelaksanaan Undang-undang Nomor 1Tahun 1974 tidak secara tegas menyebutkan bahwa lesbi dapat dijadikan alasan sang suami untuk melakukan perceraian. Tetapi bila melihat pada Pasal 39 ayat (2) Undang-undang No.1 Tahun 1974 tentang perkawinan mengaatakan" Untuk melakukan perceraian harus ada cukup alasan, bahwa antara suami isteri itu betul-betul tidak akan hidup rukun sebagai suami isteri. Hal ini didasarkan pada Pasal 34 ayat (3) yaitu " Jika suami atau isteri melalaikan kewajibannya masing-masing maka salah satu pihak dapat mengajukan gugatan kepada Pengadilan". 
Kata-kata melalaikan apabila dianalisa, maka kewajiban, banyak arti yang dapat diambil dari kata-kata tersebut. Kewajiban berumah tangga yaitu memenuhi kebutuhan keluarga baik jasmani maupun rohani, kewajiban terhadap rohani disini termasuk terpenuhinya kebutuhan biologis. Bila kewajiban kebutuhan biologis tidak terpenuhi, maka dikhawatirkan akan berdampak besar terhadap keharmonisan rumah tangga. Bila hal ini terus-menerus terjadi, dan salah satu pihak berniat cerai maka alasan ketidak harmonisan tersebut dapat dijadikan alasan untuk bercerai.

\section{Pertimbangan Hakim Dalam Putusan Pengadilan Agama Ambon Nomor 110/Pdt.G/2016/PA.Ab}

Penggugat telah mengajukan surat gugatan cerai yang terdafatar di Kepaniteraan Pengadilan Agama Ambon tanggal 25 Januari 2016 dibawah register perkara Nomor 34/Pdt.G/2016/PA Ab dengan mengemukakan alasan-alasan tanggal 22 April 2005, Pemohon dan Termohon melangsungkan pernikahan di Tandes yang dicatat oleh Pegawai Pencatat Nikah Kantor Urusan Agama Tandes, Kota Surabaya sebagaimana tercatat dalam Buku Kutipan Akta Nikah Nomor xx7/23/IV/2005.

Setelah menikah Pemohon dan Termohon bertempat tinggal di rumah dinas dokter di Namlea. Selama pernikahan antara Pemohon dan termohon telah hidup rukun sebagaimana layaknya suami istri dan telah dikarunia 2 orang anak masing-masing bernama M N E, laki-laki umur 9 tahun dan M F R, laki-laki umur 7 tahun.

Sejak bulan Juni 2010 kehidupan rumah tangga Pemohon dan termohon mulai tidak harmonis ditandai dengan adanya perselisihan dan pertengkaran disebabkan antara lain : 1) Termohon tidak mau mendengar kata-kata suami; 2) Termohon tidak mau memberikan nafkah bathin kepada Pemohon; 3) Termohon mengaku sebagai LGBT.

Puncak keretakan hubungan rumah tangga antara Pemohon dengan Termohon tersebut terjadi pada bulan September 2010. Saat itu Termohon tidak mau melayani Pemohon sebagaimana layaknya suami istri. Sejak saat itu Pemohon dan Termohon telah pindah rumah, masing-masing pihak tidak lagi menjalankan kewajibannya sebagai suami istri.

Berdasarkan dengan kejadian tersebut rumah tangga Pemohon dan Termohon sudah tidak dapat dibina dengan baik sehingga tujuan perkawinan untuk membentuk rumah tangga yang sakinah, Mawaddah dan warahmah sudah sulit dipertahankan lagi, 
dan agar Pemohon tidak melanggar norma hukum dan norma agama, maka perceraian merupakan alternatif terakhir bagi Pemohon untuk menyelesaikan permasalahan antara Pemohon dengan Termohon.

Berdasarkan alasan-alasan yang Pemohon uraian di atas, maka Pemohon mohon kepada Bapak Ketua Pengadilan Agama Ambon, berkenan memeriksa dan mengadili perkara ini, selanjutnya menjatuhkan putusan yang amarnya berbunyi: 1) Mengabulkan Permohonan Pemohon; 2) Menyatakasn memberi izin kepada Pemohon untuk berikrar menjatuhkan talak satuj raj'i terhadap Termohon; 3) Biaya Perkara menurut Hukum yang berlaku.

Alasan pemohon mengajukan permohonan cerai adalah karena sering terjadi perselisihan dan pertengkaran disebabkan karena Termohon tidak bersedia lagi melayani Pemohon untuk berhubungan badan, bahkan Termohon menyatakan bahwa Termohon menyukai sesama jenis yang mengakibatkan tidak ada ketenteraman dalam rumah tangga.

Akibat prilaku Termohon tersebut, maka Pemohon telah berpisah tempat tinggal dengan Termohon sejak bulan September 2010 sampai dimasukkannya permohonan cerai ini dan sejak itu pula kedua belah pihak sudah tidak saling memperdulikan lagi.

Membuktikan dalil-dalil permohonannya, Pemohon mengajukan dua orang saksi menyatakan bahwa pemohon dan Termohon telah terjadi perselisihan dan pertengkaran karena Termohon tidak mendengar nasehat Pemohon sebagai suami dan Termohon tidak bersedia lagi melayani Pemohon sebagaimana bahwa dalam perkara ini tidak dilaksanakan proses mediasi, karena Tergugat tidak datang menghadap di persidangan, meskipun telah dipanggil secara resmi dan patut.

Berdasarkan bukti yang dinilai Majelis Hakim sebagai Akta Autentik yang telah memenuhi syarat formil dan materil, maka Pemohon dan Termohon adalah suami istri sah yang menikah pada hari Jum'at tanggal 22 April 2005. Berdasarkan bukti yang menjelaskan bahwa Pemohon sebagai Pegawai Negeri Sipil telah memperoleh izin dari atasan sesuai PP No.45 Tahun 1990, sehingga bukti tersebut telah memenuhi syarat formal dan materiil serta mempunyai kekuatan pembuktian yang sempurna dan mengikat.

Alasan pemohon mengajukan permohonan cerai adalah karena sering terjadi perselisihan dan pertengkaran disebabkan karena Termohon tidak bersedia lagi 
melayani Pemohon untuk berhubungan badan, bahkan Termohon menyatakan bahwa Termohon menyukai sesama jenis yang mengakibatkan tidak ada ketenteraman dalam rumah tangga.

Akibat prilaku Termohon tersebut, maka Pemohon telah berpisah tempat tinggal dengan Termohon sejak bulan September 2010 sampai dimasukkannya permohonan cerai ini dan sejak itu pula kedua belah pihak sudah tidak saling memperdulikan lagi. Membuktikan dalil-dalil permohonannya, Pemohon mengajukan dua orang saksi menyatakan bahwa pemohon dan Termohon telah terjadi perselisihan dan pertengkaran karena Termohon tidak mendengar nasehat Pemohon sebagai suami dan Termohon tidak bersedia lagi melayani Pemohon sebagaimana Mengingat, Pasal 19 huruf (f) Peraturan Pemerintah No. 9 Tahun 1975 dan Pasal 116 huruf (f) Kompilasi Hukum Islam.

Berdasarkan ketentuan Pasal 89 ayat (1) Undang-Undang No.7 Tahun 1989 yang telah diubah dengan Undang-Undang No. 3 Tahun 2006, dan Undang-Undang No.50 Tahun 2009 Tentang Perubahan Kedua Atas Undang-Undang No.7 Tahun 1989, biaya perkara dibebankan kepada pemohon.

Berdasarkan gugatan yang diajukan oleh penggugat, maka majelis hakim Pengadilan Agama Ambon memberikan putusan yang amarnya berbunyi: 1) Menyatakan Termohon yang telag dipanggil secara resmi dan patut untuk menghadap dipersidangan, tidak hadir; 2) Mengabulkan permohonan Pemohon secara verstek; 3) Memberi izin kepada Pemohon untuk menjatuhkan talah satu raj'i terhadap Termohon di depan sidang Pengadilan Agama Ambon; 4) Memerintahkan Panitera Pengadilan Agama Ambon untuk mengirimkan salinan penetapan ikrar talak kepada Pegawai Pencatat Nikah Kantor Urusan Agama Kecamatan Tandes, Kota Surabaya dan Kantor Urusan Agama Kecamatan Namlea, Kabupaten Buru untuk dicatat dalam daftar yang disediakan untuk itu; 5) Membebankan kepada Pemohon untuk membayar biaya perkara sejumlah Rp. 271.000, (dua ratus tujuh puluh satu ribu rupiah).

Hakim dalam memutus perkara pada dasarnya mengacu pada peraturan perundangan yang berlaku di negara kita, namun demikian Hakim tidak hanya mempertimbangkan masalah peraturan yang sifatnya teoretis semata melainkan juga mempertimbangkan hal-hal konkret lainnya yang ada di setiap perkara, yang tentunya tidak sama satu dengan yang lainnya. 
Vol 2, No. 2, Desember 2019, DOI: https: / /doi.org/10.34007/iehss.v2i2.99

Berdasarkan putusan Pengadilan Agama Ambon Nomor 110/Pdt.G/2016/PA Ab yang terkait dengan salah pihak yang melakukan penyimpang seksul sehingga rumah tangga yang seharusnya tercipta harmonis dan menjadi keluarga sakinah mawaddah rahma itu tidak tercapai dikarenakan salah pihak kelainan seksual. Namun dalam perkara tersebut tidak dicantumkan secara jelas dikarenakan kelainan seksual (Lesbian) dianggap tabu dibicarakan disamping itu, juga pelaku merasa akan mendapat deskriminasi dari masyarakat sehingga penggugat cenderung tidak memasukan langsung kedalam duduk perkaranya tentang apa yang sebenarnya dipertengkarkan terus menerus.

Majelis Hakim Pengadilan Agama Ambon dalam kasus kelainan seksual (Lesbian) langsung menimbang bahwa hal tersebut sesuai dengan ketentuan dalam pasal 39 ayat 2 Undang-Undang Nomor 1 Tahun 1974 beserta penjelasannya pada huruf e dan huruf $\mathrm{f}$ jucto Pasal 19 huruf f Peraturan Pemerintah Nomor 9 Tahun 1975, Pasal 116 huruf e dan huruf f Inpres No. 1 tahun 1991 tentang Kompilasi Hukum Islam (KHI).

Majelis Hakim Pengadilan Agama Ambon dalam pertimbangan kasus kelainan seksual, mereka memaknai bahwa konsep pernikahan menurut Hukum Islam yaitu pernikahan atau akad yang kuat untuk menaati perintah Allah dan melaksanakannya merupakan Ibadah, tetapi dalam rumah tangga Penggugat dan Tergugat, hak dan kewajiban sudah tidak bias dilaksanakan.

Menurut Majelis Hakim apabila rumah tangga Penggugat dan Tergugat tetap dipertahankan, maka akan mengakibatkan hal-hal yang tidak diinginkan antara keduanya, karena itu Majelis Hakim menilai menolak kemudharatan harus lebih didahulukan dari pada mencari dan memperoleh kemaslahatan.

Berdasarkan putusan Pengadilan Agama Ambon Nomor 110/Pdt.G/2016/PA Ab, maka menurut penulis lesbian dapat menjadi alasan perceraian karena dari adanya homoseksual tersebut dapat menimbulkan perselisihan dan percekcokan dalam rumah tangga itu sendiri walaupun di dalam Pasal 116 Kompilasi Hukum Islam yang mengatur tentang alasan-alasan perceraian, tidak diatur mengenai lesbian sebagai alasan perceraian itu sendiri.

Kelainan seks salah salah pasangan menurut penulis dapat menimbulkan perselisihan antara terus menerus antara suami dan isteri. Hal ini sesuai dengan Pasal 116 ayat (f) Kompilasi Hukum Islam yang berbunyi "antara suami dan isteri terus 
menerus terjadi perselisihan dan pertengkaran dan tidak ada harapan akan hidup rukun lagi dalam rumah tangga". Menurut penulis, pasal tersebut apabila dianalogikan maka perselisihan dan pertengkaran tersebut meliputi segala hal yang dapat menyebabkan terjadinya perselisihan dan pertengkaran dalam rumah tangga. Apabila diterapkan dalam kasus tersebut, perilaku seks menyimpang Tergugat (lesbian) yang menjadi penyebab terjadinya perselisihan dan pertengkaran dalam rumah tangga dapat menjadi alasan terjadinya perceraian, sehingga menurut penulis, Hakim telah tepat memberikan dasar hukum Pasal 19 huruf (f) Peraturan Pemerintah Nomor 9 tahun 1975 juncto Pasal 116 huruf (f) Kompilasi Hukum Islam sehingga dalam perkara putusan Pengadilan Agama Ambon Nomor 110/Pdt.G/2016/PA Ab, dasar pertimbangan Hakim telah sesuai dengan ketentuan undang-undang Perkawinan dan peraturan pelaksanaannya.

Pasal 19 huruf (f) Peraturan Pemerintah Nomor 9 tahun 1975 tertulis alasan perceraian yakni "antara suami dan isteri terus menerus terjadi perselisihan dan pertengkaran dan tidak ada harapan akan hidup rukun lagi dalam rumah tangga". Perselisihan dan pertengkaran yang terus menerus antara suami dan istri membuat rumah tangga laksana neraka dunia, dimana suami istri di dalamnya tersiksa, jauh dari rasa ketenangan, ketentraman dan kebahagiaan yang justru menjadi tujuan perkawinan. Penyebab terjadinya perselisihan dan pertengkaran juga bermacam-macam, antara lain adalah karena tekanan ekonomi rumah tangga, bias karena cara hidup dan pandangan yang berbeda, bisa karena kehidupan beragama yang berbeda dan juga adanya kelainan seksual seperti lesbian sebagaimana dalam kasus putusan Pengadilan Agama Ambon Nomor 110/Pdt.G/2016/PA Ab.

\section{SIMPULAN}

Pengaturan pelaksanaan perceraian di Pengadilan Agama adalah berdasarkan pada UU No. 1 Tahun 1974 dan PP No. 9 Tahun 1975 dengan alasan salah satu pihak berbuat zina atau menjadi pemabok, pemadat, penjudi, dan lain sebagainya yang sukar disembuhkan, salah satu pihak meninggalkan pihak lain selama 2 (dua) tahun berturutturut tanpa izin pihak lain dan tanpa alasan yang sah atau karena hal lain diluar kemampuannya, salah satu pihak mendapat hukuman penjara 5 (lima) tahun atau hukuman yang lebih berat setelah perkawinan berlangsung, salah satu pihak melakukan kekejaman atau penganiayaan berat yang membahayakan pihak yang lain, salah satu 
pihak mendapat cacat badan atau penyakit dengan akibat tidak dapat menjalankan kewajibannya sebagai suami/isteri, antara suami dan isteri terus menerus terjadi perselisihan dan pertengkaran dan tidak ada harapan akan hidup rukun lagi dalam rumah tangga, salah pihak yang melakukan penyimpang seksul seperti lesbian sehingga rumah tangga yang seharusnya tercipta harmonis dan menjadi keluarga sakinah mawaddah rahma itu tidak tercapai dikarenakan salah pihak kelainan seksual

Akibat hukum perceraian dengan alasan perilaku lesbian dari seorang isteri adalah berakit terhadap hak asun anak. Orang tua yang bercerai walaupun perwalian hak asuh anak jatuh kepada ayah atau ibunya, dalam hal ini kedua-duanya harus tetap seimbang untuk tetap bertanggungjawab terhadap anak dalam hal biaya kebutuhan ekonomi, pendidikan, agama dan kasih sayang, demi perkembangan jiwa, mental dan psikologis si anak. Akibat hukum terhadap harta perkawinan yaitu harta bersama dibagi menurut ketentuan hukum, undang-undang, agama dan hukum adat masing-masing yang berlaku. Sedangkan harta bawaan tetap dikuasai masing-masing pihak isteri maupun suami yang bercerai. Terhadap hutang piutang yang diakibatkan putusnya perkawinan akibat perceraian dipikul oleh kedua belah pihak dengan persyaratan yang harus dipenuhi dimana hak dan kewajiban suami dan isteri adalah seimbang dalam kewenangannya untuk melakukan perbuatan hukum.

Pertimbangan hakim dalam putusan Pengadilan Agama Ambon Nomor 110/Pdt.G/2016/PA Ab dalam kasus kelainan seksual (lesbian) langsung menimbang bahwa hal tersebut sesuai dengan ketentuan dalam Pasal 39 ayat 2 Undang-Undang Nomor 1 Tahun 1974 beserta penjelasannya pada huruf e dan huruf f juncto Pasal 19 huruf f peraturan pemerintah Nomor 9 Tahun 1975, Pasal 116 huruf e dan huruf f Inpres No. 1 Tahun 1991 tentang Kompilasi Hukum Islam (KHI).

\section{DAFTAR PUSTAKA}

Abdurrahman, M, (2009) Sosiologis dan Metode Penelitian Hukum, UMM Press, Malang.

Abufaiz, "Kota Pompai yang dijungkirbalikkan" artikel di akses pada 10 April 2019 dari http://google.com.Kot-Pompai-vang-dijungkirbalikkan.

Ali, A dan Heryani, W. (2012) Asas-Asas Hukum Pembuktian Perdata, Kencana Prenada Media Group. Jakarta,

Ali, A, (2002) Menguak Tabir Hukum (Suatu Kajian Filosofis dan Sosiologis), Gunung Agung Tbk, Jakarta.

Ali, A, Menguak Teori Hukum (Legal Theory) \& Teori Peradilan (Judicialprudence) Termasuk UndangUndang (Legisprudence), Kencana Prenada Media Group, Jakarta, 2010.

Ali, Z, (2009) Metode Penelitian Hukum, Sinar Grafika, Jakarta.

Anonim,www.pengertianmenurutparaahli.com/pengertian asas kepastian hukum, diakses Kamis, 01 Maret 2018 Pukul $21 .^{00}$ wib. 
Djubaedah, N (2010). Perzinaan Dalam Peraturan Perundang-Undangan Di Indonesia Ditinjau Dari Hukum Islam, Kencana Prenada Media Group, Jakarta,

Hadi, S, (2009) Metodologi Riset, Andi Offset, Yogyakarta.

https://id.wikipedia.org/wiki/Biseksual, diakses Kamis, 01 Maret 2018 Pukul 21. ${ }^{00}$ wib.

https://id.wikipedia.org/wiki/Gav diakses Kamis, 01 Maret 2018 Pukul 21. ${ }^{00}$ wib.

https://id.wikipedia.org/wiki/lesbian, diakses Kamis, 01 Maret 2018 Pukul 21. ${ }^{00}$ wib.

Ichsan, A, (2006). Hukum Perkawinan Bagi Yang Beragama Islam, Pradnya Paramita, Jakarta,

Kementerian Agama RI., (2010) Alquran dan Terjemahannya, Dirjen Bimbingan Masyarakat Islam dan Penyelenggaraan Haji Departemen Agama RI, Jakarta.

Kompilasi Hukum Islam

Manan, A, (2005) Pertumbuhan dan Perkembangan Konstitusi Suatu Negara, CV. Mandar Maju, Bandung,

Manan. A, (2003) Aneka Masalah Hukum Materil DalamPraktek Peradilan Agama, Pustaka Bangsa Press, Jakarta.

Manan. A, (2009) Penerapan hukum Acara Perdata di Lingkungan Peradilan Agama, kencana, Jakarta,

Mukhtar, K, (2013). Asas-Asas Hukum Islam Tentang Perkawinan, Bulan Bintang, Jakarta,

Peraturan Pemerintah Nomor 9 Tahun 1975 Tentang Pelaksanaan Undang-Undang Nomor 1 Tahun 1974 Tentang Perkawinan

Ramulyo, I.M. (2001) Tinjauan Beberapa Pasal Undang-Undang No.1 Tahun 1974, Segi-Segi Hukum Perkawinan Islam, Ido Hilco, Jakarta,

Ramulyo, I.M. (2006). Hukum Perkawinan Islam Suatu Analisis Dari UU No. 1 Tahun1974 dan Kompilasi Hukum Islam, Bumi Aksara, Jakarta,

Sadhily, H.et. al. (2015) Ensiklopedi Indonesia, Ghalia Indonesia, Bogor,

Sastroatmojo, A, (2003). Hukum Perkawinan, Bulan Bintang, Jakarta,

Soekanto, S, (2004) Faktor-Faktor Yang Mempengaruhi Penegakan Hukum, PT. Raja Grafindo Persada, Jakarta.

Soekanto, S, (2005). Penelitian Hukum Normatif "Suatu Tinjauan Singkat", Rajawali Pers, Jakarta,

Soekanto, S, (2006). Pengantar Penelitian Hukum, UI Pers, Jakarta,

Soekanto, S, (2010) Sosiologi Keluarga: Tentang Ikhwal Keluarga, Remaja dan Anak, Jakarta: Rineka Cipta,

Soemitro, R.H, (2004). Metodologi Penelitian Hukum dan Jurimetri, Ghalia Indonesia, Jakarta, Soemiyati, 2012 Hukum Perkawinan Dan Undang-Undang Perkawinan, Liberty, Yogyakarta,

Undang-Undang Nomor 1 Tahun 1974 Tentang Perkawinan

UUD 1945 Hasil Amandemen dan Proses Amandemen UUD 1945. 